\title{
Demographic Fluidity and Moral Ecology: Queenstown (Tasmania) and a Lesson in Precarious Process
}

\begin{abstract}
It is argued that communities embodying the conditions identified by Karl Jacoby as constituting a moral ecology are threatened by processes of gentrification, these now gathering pace throughout the western world. These communities may evince an environmental sensibility, but such a sensibility will not be the moral ecology of which Jacoby writes, the latter requiring the development, through time, of mores of sustainability forged through a long and intimate engagement by a community with its ambient environment. The paper examines changing environmental attitudes within the Tasmanian mining town of Queenstown as a lens through which his argument can be demonstrated.
\end{abstract}

\section{Introduction}

Karl Jacoby's adaptation of E.P. Thompson's thesis of “the moral economy of the English crowd in the Eighteenth Century" ${ }^{1}$ into a theory of long-term local ecology/local community sustainability is compelling in both concept, evidence and argument. This notwithstanding, it is argued here that Jacoby's case ${ }^{2}$ for a "moral ecology" could be usefully enriched through recognition that there is a fragility to moral ecology; a precarious element pertaining to both its formation and capacity for longevity. The development of moral ecology can be frustrated by the channelling of community ethics into non-compatible pathways, and its longevity can be threatened by several factors external to the moral ecology context. Jacoby points to one of these - externally-imposed "conservation" regimes driven by science and policy imperatives formulated in remote cities. I have myself pointed to another - the obliteration of community-controlled resource-based industry by state-promoted industry existing at a scale and with a decision-making locus that pays scant regard to local ways and mores. $^{3}$

But other factors can be adduced, most notably the unprecedented rates of demographic fluidity within the western world today. The threat this poses is, of course, to the longevity of the traditional community itself, and where a community dissolves, so, necessarily, does the moral ecology it has sustained. Rural and small-town gentrification now probably constitutes the greatest

\footnotetext{
${ }^{1}$ E.P. Thompson, Customs in Common (New York: The New Press), 185-351.

${ }^{2}$ Karl Jacoby, Crimes against Nature: Squatters, Poachers, Thieves and the Hidden History of American Conservation (Berkeley, Los Angeles and London: University of California Press, 2001).

3 Hay, Pete, "'Balding Nevis': Place Imperatives of an Invisible Cohort within Tasmania's Forest Communities," Geographical Research 46, no. 2 (June 2008): 224-233.
} 
threat to moral ecology, then. Such gentrification does not pose a threat to the presence of ecological values per se, but we need to acknowledge that the existence of conservationist values is not, of itself, sufficient to constitute moral ecology. A gentrified rural community may well possess such values, but they will not be the specific, time-honed relations of reciprocity identified and described by Jacoby, these requiring the persistence of communities of long-standing.

I develop this case through an investigation of the (in)famous mining town, Queenstown, on Tasmania's West Coast. Queenstown is as much a misfit within Australia's landscape iconography as it is possible to be - cold, not hot; wet, not dry; mountainous, not flat; tangled temperate forest, not sandy desert. Its history has been fashioned by mining; within a national context, it is one of a handful of Australia's larger-than-life mining communities. I have had four periods of immersion in the life of Queenstown, and it is the data gathered on three of these occasions that form the basis of the case presented here. The first of these took place late in 1993, when I was employed as a consultant by the State Government to ascertain what regime, if any, the people of Queenstown wanted implemented to promote or prevent reforestation of the famous denuded hills that have provided such a dramatic background to the township. The details of my project are given at the appropriate place in the paper. My second sustained stint took place in 2015, when I undertook a creative writing residency in Queenstown. I was there to produce an essay on the 1903 visit to the West Coast by the English socialist firebrand, Tom Mann, and to generate a body of Queenstownthemed poetry. Since then I have accepted a position on the Creative Directorate of The Unconformity, a high-end Queenstown arts festival held for the first time in 1916. I took advantage of this commitment to interview six of Queenstown's opinion leaders, and insights gained thereby have also informed the paper.

\section{E.P. Thompson and the idea of the Moral Economy}

When E.P. Thompson formulated his concept of the "moral economy" he assumed, wrongly in part, that it was historically bounded; that the construction of an economy based upon informal rules of reciprocity could not survive the advent of the hyper-rationalist economic formalisation of industrial capitalism. The old economy of reciprocity did not go down without a fight: it is central to Thompson's analysis of the English food riots in the eighteenth century: "the men and women in the crowd were defending traditional rights and customs." 4 Their actions, in general, "operated within a popular consensus as to what were legitimate and what were illegitimate practices in marketing, milling, banking, etc.," and this was "grounded upon a consistent traditional view of social norms and obligations, of the proper economic functions of several parties within the community, which, taken together, can be said to constitute the moral economy of the poor." ${ }^{5}$.

\footnotetext{
${ }^{4}$ E.P. Thompson, "The Moral Economy of the English Crowd in the Eighteenth Century," Past and Present 50 (February 1971): 78.

${ }^{5}$ Thompson, "Moral Economy," 79.
} 
Thompson was adamant that the triumph of the "political economy of the free market" was so comprehensive as to signify the "final demise"' of the moral economy ${ }^{6}$. But a socially constructed view of the norms and obligations of parties within any given community remains a significant aspect of social discourse and power relations within that community. As I observed in an earlier paper, "most contemporary commentators... proceed from an assumption that [the moral economy] is not historically bounded - and certainly not insofar as its normative relevance is concerned." argued that "vernacular and organic formulations of the moral economy have survived to become, now, a discourse of resistance to the amoral and place-obliterating interactions of the global market." ${ }^{8}$ Further, "the place discourse not only accords with the moral economy tradition - it may be that the former has become the latter's contemporary standard-bearer, for much of the literature of place contains observations that correspond with the idea of the moral economy." ${ }^{\prime 9}$ Much literature of place valorises the re-construction and/or preservation of local economic and social relations of reciprocity. Likewise, scholarly attention has been drawn to analysis of local socioeconomic systems and their relations with other characteristics of place, particularly the natural setting within which communities function.

\section{Jacoby, Hay, and the Idea of Moral Ecology}

In 2001 the American scholar, Karl Jacoby, took Thompson's idea of the moral economy as an economy of informal, trust-based reciprocal relations and applied it to a mode of relationship between "the community, its socio-economic norms and practices, and the natural world upon which they draw - and this, too, is an ethical relationship."10 Jacoby studied local conservation norms and practices within communities in the Adirondacks, around Yellowstone, and at the Grand Canyon, describing his project thus:

I seek to recreate the moral universe that shaped local transgressions of conservation laws, enabling us to glimpse the pattern of beliefs, practices and traditions that governed how ordinary rural folk interacted with the environment - a pattern that, paraphrasing E.P. Thompson, I have come to term the participants' moral ecology. This moral ecology evolved in counterpoint to the elite discourse about conservation, a folk tradition that often critiqued official conservation politics, occasionally borrowed from them, and at other times even influenced them. Most of all, though, this moral ecology offers a vision of nature 'from the bottom up'... ${ }^{11}$

Jacoby's coinage of "moral ecology", then, identifies quite specific relationships of reciprocity and trust between grounded, place-attuned individuals, their local communities, and terrain recognised (both internally and externally) as embodying significant ecological values. He points to a mismatch of value between officially imposed, often protectionist, policy regimes, and communal mores that have, over time, "fashioned a variety of arrangements designed to safeguard the ecological basis of

\footnotetext{
6 Thompson, "Moral Economy", 136.

${ }^{7}$ Hay, 'Balding Nevis', 228-29.

8 Hay, 'Balding Nevis', 229.

${ }^{9}$ Hay, 'Balding Nevis', 229.

${ }^{10}$ Hay, 'Balding Nevis', 229.

11 Jacoby, Crimes against Nature, 3.
} 
their way of life." ${ }^{\prime 2}$ Though it is more nuanced than this (as the quote above indicates), for Jacoby the counterpoint to his moral ecology is professional conservation, characterised by its external and science-based derivation, and its official codification and sanctioning. Against the preservationist ethic of much official environmentalism, Jacoby sets an ethic of sustainable use, this being necessary to enable a treasured way of life to continue, one based on a mandated usage, but a usage that is governed by a time-forged and time-honoured ethic of wise husbandry. His sympathies are firmly with the latter; indeed, he makes a grand claim for his findings: that "the belief that prior to the advent of conservation, rural folk, in keeping with the supposed rugged individualism of the American frontier did as they pleased with the natural world, ${ }^{13}$ fails the test of empirical investigation.

In 2008, the present author took Jacoby's formulation of a grounded moral ecology and applied it to a community of small sawmillers in the high country of the upper North Esk valley in the southern Australian island, Tasmania. This is an island similar to Sri Lanka and Ireland in size, though with a population of only half a million people, and with a pronounced conservation sensibility. Much of it is uninhabited, under dense wetland forest, and accorded national park and even World Heritage status - and is managed accordingly. A mountain national park abuts the northeast uplands that were the focus of my investigation, and the park is managed for preservationist purposes (although it contains a ski field). The only commercial use activities permitted therein are normally, then, activities associated with tourism. Nevertheless, the adjacent region "is currently the epicentre of perhaps the most rapid conversion of native forest to plantation on the island." In terms of infrastructure, "there is no shop, school or church, not even a graveyard," though "this was once core sawmilling country, with a network of self-contained villages attaching to each mill." Now "there are only the diehards left, small sawmillers - not necessarily even old - retired millers, retired 'fallers' (as they call themselves), more men than women, and, as yet, no sea-changers." ${ }^{14}$ This last observation will be of increasing relevance to the argument mounted in this paper.

I found, among these remnant timber communities, a strong expression of the reciprocal personenvironment relationship that Jacoby has described, with the significant variation that, in the case of the sawmillers of Tasmania's upper North Esk valley, the assertion of the relationships of reciprocity that characterise the condition of a moral ecology was not articulated in opposition to environmental agencies and externally-imposed conservation regimes, but in opposition to aggressive, externally-imposed forestry regimes, and the capital-city based agencies that promulgated them. I supplied elaborative quotes from interviews; for example:

That bush up there is all I know. I can take you up there and show you how the wind shifts when you go a yard or so that way, and how the temperature pools differently over there. And this summer they'll flatten that bush. They'll plant it out in nitens [the favoured eucalypt, one not native to Tasmania, of Tasmanian plantation practices], but it wouldn't

\footnotetext{
12 Jacoby, Crimes against Nature, 193.

13 Jacoby, Crimes against Nature, 193.

${ }^{14}$ Hay, 'Balding Nevis', 226.
} 
matter if they let it grow back - it still wouldn't be the bush I know. And that's all I know. They might as well cut my brain out. ${ }^{15}$

I catalogued the elements of the pronounced moral ecology of this largely unrecognised cohort within Tasmania's timber communities. These include a contempt for forest science and a strongly expressed affirmation of the value of careful vernacular observation; a sadness for the fate of fauna destroyed through the application of clearfell technologies; and pride in the old forest worker's craft: "'we used to spend hours working out how to fall a tree so as to do the least damage to the forest', said one retired 'busher" - another local colloquialism - and then, with bitterness: 'I don't know why we bothered."'16

\section{A Suitable Site for Investigation? Queenstown, Tasmania's Iconic Mining Town}

Searching for another Tasmanian site against which to test the moral ecology paradigm, I hit upon the western mining town of Queenstown, a town almost as geographically distant from the upper North Esk as it is possible to be in Tasmania, and one with a different economic base, different cultural traditions, and a different ambient ecology (though there are similarities here in some respects).

Queenstown sits within a cold and mountainous terrain of tangled wet temperate forests rainforest connected by an ancient lineage to the Gondwana supercontinent; wet sclerophyll forest that, although dominated by more recent planetary arrivals - eucalypts - contains ancient Gondwanan rainforest species; and sodden "button grass" moorlands dominated by sedges and heaths, which occur within flat valleys of poorly-drained, peaty soils entirely unsuited for agricultural production. They are, indeed, "some of the most nutrient poor situations to be found in the world." ${ }^{17}$ Aboriginal people dwelt in the region, though mainly near the coast, and for almost a hundred years after the arrival of Europeans it was of scant interest to colonial settlers. Today the vast majority of lands surrounding Queenstown are within national parks which have been accorded World Heritage Area status by UNESCO, listed for both natural and cultural values, although primarily for the former.

The scarcely-penetrable forests of the West Coast held a secret, though - a highly mineralised ore belt (the Cambrian Mt. Read Volcanics), which runs almost the length of the coastal hinterland. As early as the 1850s speculation persisted that fabulous riches were to be found below the forests and moorlands. Initially defeated by the forbidding nature of terrain, climate and flora, from the midnineteenth century a small number of true believers prosecuted the search for a Tasmanian Eldorado. Enough intriguing indicators were reported to maintain enthusiasm and, finally, in 1873, a

\footnotetext{
${ }^{15}$ Quoted in Hay, 'Balding Nevis', 228.

${ }^{16}$ Quoted in Hay, 'Balding Nevis', 227.

17 “Buttongrass Moorland - A Unique Habitat," Parks and Wildlife Service Tasmania, accessed August 18, 2017, www.parks.tas.gov.au/?base=3224.
} 
determined farmer-turned-prospector, James ("Philosopher") Smith found payable tin near Mt. Bischoff, towards the north of the mineralised belt, tipping what had previously amounted to little more than curious scratchings into an earnest "rush". The search for profitable ore bodies was on in earnest. ${ }^{18}$

The pattern of settlement that ensued was typical of gold rush country. Mines were opened up and new towns sprang into existence with the civic confidence that signifies an expectation of permanence - the perpetual myth of mining towns everywhere. Inevitably, most of these passed away as quickly as they came, the main streets with their grand hotels rapidly swallowed by the fecund bush. Some few generated significant wealth, though briefly - and one did make good its presumption of permanence, surviving, albeit barely, the vicissitudes of economic uncertainty that invariably characterise mining economies, and giving rise to a combative place mythology along the way which has been both a consequence and a cause of its communal resilience. This is Queenstown.

Queenstown came into being in the early 1890 s as a gold rush shanty town on the banks of the thenbeautiful Queen River. The fledgling village, Penghana, was razed by fire in 1896, but a new town with a new name quickly came into existence a little further downriver. Mining here was not, in the main, characterised by the endeavours of the heroic individual. With attention not on gold, but copper, Queenstown was soon became the preserve of capital-intensive enterprise, which ultimately coalesced into two companies. The portentous early history of Queenstown features a dramatic struggle between these two colossi, the North Mount Lyell Copper Co. and the Mt. Lyell Mining and Railway Company. The resultant 1903 merger, very much to the favour of the latter - indeed, the newly merged entity retained the latter's name - was, in Blainey's words, "the greatest merger in Australian mining history," one in which "the largest and the fourth-largest copper producers in the British Empire... were one." ${ }^{19}$ Queenstown's prosperity was guaranteed, grand buildings proliferated (many of them extant, endowing Queenstown with a main street - Orr Street - characterised by a dramatic grandeur), and the town set about acquiring a distinctive place mythos.

Much of this has to do with the drama of the surrounding landscape. The central figure in Queenstown history is Robert Sticht, "a short, scholarly American"20 (Blainey 1967, 74) given, in his private life, to obsessive collecting. ${ }^{21} \mathrm{He}$ arrived in Queenstown in 1885 as chief metallurgist for the

${ }^{18}$ C.J. Binks, Pioneers of Tasmania's West Coast (Hobart [Tasmania]: Blubber Head Press, 1988), 11-25; Geoffrey Blainey, The Peaks of Lyell, $3^{\text {rd }}$ edn. (Carlton [Victoria]: Melbourne University Press, 1967), 12-19; Margery Godfrey, Waratah: Pioneer of the West (Waratah [Tasmania]: Municipality of Waratah and Morevale Investments, 1984), 2-9; Nic Haygarth, Baron Bischoff: Philosopher Smith and the Birth of Tasmanian Mining (no place listed: self-published, 2004); Charles Whitham, Western Tasmania: A Land of Riches and Beauty (Queenstown [Tasmania]: Board of Management, Robert Sticht Memorial Library, 1949), 74-7.

${ }^{19}$ Geoffrey Blainey, The Peaks of Lyell, $3^{\text {rd }}$ edn. (Carlton [Victoria]: Melbourne University Press, 1967), 161; for a detailed account of the events leading up to and immediately consequent upon this merger, see Blainey, Peaks of Lyell, 102-74.

${ }^{20}$ Blainey, Peaks of Lyell, 74.

${ }^{21}$ Heather Gaunt, "Robert Sticht and the Relics of the Past", In The Jewelled House of Art and Nature: The Mt. Lyell Mining and Railway Company Office, ed. Raymond Arnold and Travis Tiddy (Queenstown [Tasmania]: Mt Lyell Office Development Committee, 2010). 
Mt. Lyell Company, and in 1903 took control of the newly-merged company as General Manager. He was, Blainey observes, "probably the greatest figure in the huge Australian mining industry of the day." 22 Sticht was a man of mercurial temperament and of technical genius. He pioneered pyritic smelting - indeed, he was the world's foremost champion of it. This was "the most attractive in theory of all smelting techniques, for it utilized the heat generated by the combustion of the iron and sulphur in the in the pyritic ore as a fuel in the furnace, thus dispensing with large quantities of expensive coke. But the process was full of practical pitfalls... " ${ }^{23}$ Sticht was accustomed to getting his way, and the force of his character overrode all opposition. So it was that Mt. Lyell had bestowed upon it the world's first successfully operating pyritic smelter.

The most visible long-term consequence was the creation of the "lunar landscape" for which Queenstown became notorious, and for which Sticht's new smelting process was in largest part responsible:

Sulphur was the curse of Mt. Lyell. When the big company smelted its pyrite in ten or eleven furnaces Queenstown found its climate changing. In still weather sulphur from the smelters thickened fogs into pea-soupers, choked Queenstown, and blanketed the valley. For days on end men working in the flux quarries on the hills above the town basked in the winter sun, and looked down on the creamy waste of cotton wool in the valley... Sulphur was in every breath of air; even tobacco lost its taste. ${ }^{24}$

The sulphurous fumes given off by the smelting process poisoned the surrounding vegetation over a very large area, though an unsustainable rate of tree falling and almost annual wildfires also contributed to the rapid denudation of the mountains. Once stripped - and the surrounding hills, mountains and valleys were entirely denuded by 1900 - "the omnipresent rain eroded the mountain to bare rock." 25 The same processes that had caused the denudation also conspired to preclude regrowth.

Sticht's mettlesome nature was also one that had no truck with organised labour. And his workforce was militant. Unionism came early to Queenstown, and Sticht's first decade in charge of the company was spiced by several rancorous strikes. Leftist agitators abounded in both mine and town. Though he lived in Melbourne, the colourful Labor pioneer, King O'Malley, represented the miners in the new federal parliament. The English-speaking world's most prominent socialist agitator, Tom Mann, was twice on the West Coast in the early 1900s. West Coast newspapers tended to take the view of the men, not management. In 1912 an underground fire at the North Lyell mine killed 42 miners, after which time the company recognised Sticht's bellicose attitude towards the men as unhelpful, and responsibility for labour relations shifted to his talented deputy, Russell Murray. ${ }^{26}$

\footnotetext{
22 Blainey, Peaks of Lyell, 161.

${ }^{23}$ Blainey, Peaks of Lyell, 74.

24 Blainey, Peaks of Lyell, 99.

25 Pete Hay, "'These Blarsted Hills": Affectionate Regard for a Despoliated Landscape', In Vandiemonian Essays (Hobart [Tasmania]: Walleah Press, 2002), 73; see also Blainey, Peaks of Lyell, 100-101.

${ }^{26}$ Ann G. Smith, “Murray, Russell Mervyn (1877-1945)," Australian Dictionary of Biography, accessed May 22, 2018, http://adb.anu.edu.au/biography/murray-russell-mervyn-7713/text13509, hardcopy 1986; Blainey,
} 
In this decade, the fundamentals of Queenstown's combative sense of place were formed. In 1900 the town was the third largest in Tasmania, with a population in excess of 5000, rising to 11000 once the inhabitants of several nearby hamlets and mining camps are added in. Blainey thinks "the summer of 1902-3", immediately prior to the company amalgamations, was when "the Mt Lyell field was probably most populous." 27 This sense of confidence in the perpetuity of the mine, and the fierce, future-focused socialist politics subscribed to by working families, supplied the bedrock of a muscular, workingman's weltanschauung, central to which was a conventional pioneering ethos with its strong belief in the utility (as opposed to the intrinsicality) of the natural world, and, slightly less conventionally, a faith that the workingman's paradise would be a manly, industrialised one, a future in which the inevitable conversion of Marx's "first nature" into "second nature" would be complete. ${ }^{28}$ Far from a source of communal shame, the bare, eye-blindingly white landscape was a source of communal pride, evidence of "man's" heroic capacity to wrest an exclusively human prosperity from the gifts of nature.

Over the next hundred years the town's fortunes fell victim to the whims of a volatile copper market, and a steadily declining resource. Though by all measure this has to be accounted an extremely profitably mine, it underwent, through the second half of the twentieth century, death by a thousand cuts. In 1963 the last of the famous Abt-system trains left Queenstown for the coastal port of Strahan (the railway has since re-opened as a tourist venture, though without the remarkable central cog mechanism that hauled trains up the 1:16 gradients ${ }^{29}$ ). In 1965, the refinery, set up in 1928 to much fanfare, closed. The smelters that had so revolutionised mining 70 years beforehand ceased work on Christmas Eve, 1969, and the last shipment of smelted copper left Strahan early the following year. The "open cut" closed in 1972. Major mine retrenchments occurred periodically thereafter -400 jobs were lost in one hit in 1974, for example. Queenstown bled population. Brass bands amalgamated and then passed away. The 13 pubs that existed in 1903 had become four by the end of the century. In 1994 the Western Tasmanian Football Association folded, leaving only a single team to carry on playing that most physically demanding of games, Australian football, on Queenstown's famous gravel oval. And the mine itself closed in 1994 - though its imminent reopening is constantly rumoured.

Through all these vicissitudes Queenstown's fiercely articulated sense of place remained intact, perhaps even strengthening as the town's economic basis slowly eroded. As I once wrote (with an excess of lyricism, perhaps) in a West Coast-themed art exhibition catalogue essay:

The struggle of this pitiless world and its elemental familiars takes on an essential heroism. Up the rivers, winning the gold heart from the pine, living a life as unmediated as any white lives have been lived in this country. Heroic. Fighting Gondwana off the Queenstown mountains. Heroic. Tom Mann scattering visions of the End of History. King O'Malley all fire

Peaks of Lyell, 265-7. Murray succeeded Sticht as General Manager in 1922. He retired in 1944, and his son, Hugh Murray, became General Manager in 1948.

27 Blainey, Peaks of Lyell, 173.

28 On this distinction see Karl Marx and Friedrich Engels, The German Ideology (London: Lawrence \& Wishart, 1965 [ms 1846]), 58.

${ }^{29}$ Lou Rae, The Abt Railway on Tasmania's West Coast (Sandy Bay [Tasmania]: self-published, 1988). 
and socialist brimstone from the balcony of Hunter's Hotel. The flame of revolution ablaze in the mines. Heroic. ${ }^{30}$

In the 1970s Queenstown's "heroic" productivist place mythos came under sustained attack. The former port town of Strahan, situated as it is on a large sunken harbour into which disgorges Tasmania's grandest river, the Gordon, had already started to reconstruct itself as a tourist town rather than an industrial port. It looked inland and up the mighty river rather than out to the sea, its local economy increasingly river tour based. When the state government, its world-view very much in line with that of Queenstown, proposed a large hydro-electric dam on the lower Gordon River, a dam that would swallow up the lower reaches of the Gordon's major tributary, the Franklin (the last major river still "wild", in the sense that no part of its system was dammed), a wilderness preservation movement swung into action. It was already tactically and strategically fine-tuned from the recently lost battle to save Lake Pedder from inundation; and the Save the Franklin campaign was born. This was to be Australia's first nationally-scoped wilderness preservation battle, the conflict dramatically fought out in the glare of national television on the river itself. It played a crucial role in the election of the Labor Party in the 1983 federal elections, and the river was finally saved when the High Court ruled 4-3 that the Federal Government had the constitutional power, through its international responsibilities as a signatory to the World Heritage Convention, to override the State of Tasmania in matters pertaining to the World Heritage Area, within which the dam was to have been built.

It is unnecessary to reprise here descriptions of this tumultuous time in Tasmanian politics. It has been much analysed previously. ${ }^{31}$ What is significant for our present purposes is how these events

\footnotetext{
${ }^{30}$ Cited in Pete Hay, "'These Blarsted Hills: Affectionate Regard for a Despoliated Landscape", in Vandiemonian Essays, (Hobart [Tasmania]], Walleah Press, 2002), 70.

${ }^{31}$ For example, Tim Bonyhady, "The Photo That Changed Us," Weekend Australian, Features Section, April 2021, 1996; Bob Brown, "Wilderness Versus Hydro-Electricity in South West Tasmania," in Fighting for Wilderness: Papers from the Australian Conservation Foundation's Third National Wilderness Conference, ed. J.G. Mosley and J. Messer (Sydney: Fontana/Australian Conservation Foundation, 1984), 59-68; Greg Buckman, Tasmania's Wilderness Battles: A History (Sydney: Allen \& Unwin, 2008); Henry Chen and Pete Hay, "Dissenting Island Voices: Environmental Campaigns in Tasmania and Taiwan", in Proceedings, Islands of the World VIII: Changing Islands - Changing Worlds, Kinmen Island, Taiwan, 2004, 1110-31.; Bruce W. Davis, "The Struggle for South-West Tasmania," in Interest Groups and the Policy Process: Case Studies from the Australian States, ed. Roger Scott (Melbourne: Macmillan, 1980), 152-69; Gary Easthope, and Geoff Holloway, "Wilderness as the Sacred: The Franklin River Campaign," in Environmental Politics in Australia and New Zealand, ed Peter Hay, Robyn Eckersley and Geoff Holloway, 189-201. (Hobart [Tasmania]: Occasional Paper 23, Centre for Environmental Studies, University of Tasmania, 1989), 189-201; Roger Green, ed., Battle for the Franklin: Conversations with the Combatants in the Struggle for South West Tasmania (Sydney: Fontana/Australian Conservation Foundation, 1984); Pete Hay, "Will the Tasmanian Disease Spread to the Mainland?: The Politics of Tasmania's World Heritage Area," Current Affairs Bulletin 63, no. 3 (August 1987): 4-12; Geoff Law, The River Runs Free: Exploring and Defending Tasmania's Wilderness (Camberwell [Victoria]: Viking/Penguin, 2008); Doug Lowe, The Price of Power: The Politics Behind the Tasmanian Dams Case (South Melbourne [Victoria]: Macmillan, 1984); James McQueen, The Franklin: Not Just a River (Ringwood [Victoria]: Penguin, 1983; Cassandra Pybus and Richard Flanagan 1990, eds., The Rest of the World Is Watching: Tasmania and the
} 
were received in Queenstown. Unlike Strahan, which had moved on in large part (as we have seen), Queenstown remained fixated on its industrial mythos. With its mine sputtering towards closure, the thought of becoming the base for a large program of dam building fitted both its sense of selfinterest and the muscular clarity of its weltanschauung. The town was, accordingly, enraged. "Work on the Gordon-below-Franklin dam was seen as the saviour of the town," observed prominent antidam campaigner, Geoff Law, "and attempts to stop it were regarded as economic and social sabotage." 32 Protestors travelling from Hobart to the blockade's headquarters in Strahan had to pass through Queenstown, often needing to stop for fuel or food, and to do so was to risk serious violence. When the leader of the Save the Franklin campaign, Dr. Bob Brown, was assaulted by a gang of pro-dam youths in Strahan on 13 January 1983, it was taken as fact that they were from Queenstown. "The loathing," I have written, "with which the people of Queenstown fixed upon 'greenies' may not have been surpassed in Australian history." ${ }^{34}$ For the national media covering the blockade on the river the Queenstown angle was irresistible. The town found itself nationally dubbed the most anti-green community in all Australia, and on the evidence, this seems a reasonable assessment.

Even this, though, may not fully capture the depth of the town's feelings. As I have noted:

There was even a tendency to transfer hatred of greenies from the people themselves to the objects of green affection. Along the coast, and under cover of night, boat-borne saboteurs torched venerable Huon pines - how more eloquently to say "all this verdant life might impress you, but we value it at precisely nought?" ${ }^{35}$

Then, in 1982, a state election was held, and the dam was the only election issue. In Queenstown "the socialist sons and daughters of socialist mothers and fathers were suddenly voting Liberal," ${ }^{36}$ the Australian Labor Party now being seen as dangerously infected with the "green poison":

For the people of Queenstown and the West Coast the old divide over industrial class interests was now seen as less fundamental than the divide between adherents of the old humanist faith in progressive modernism... and the supporters of a new trans- or post-modern politics that rejected the very context in which the old industrial struggle was played out... Conflict's fulcrum shifts. No longer capital/labour, [it] becomes industrial modernity against ecological late-or perhaps post-modernity... And the children of red revolutionaries vote for the party of the bosses. ${ }^{37}$

\section{Queenstown in 1993: Seeking a Moral Ecology}

Greens (Sydney: Pan Macmillan, 1990); M. Sornarajah, ed., The South West Dam Dispute: The Legal and Political Issues, Sir Elliot Lewis Memorial Publication (Hobart [Tasmania]: University of Tasmania, 1983); Peter Thompson, Bob Brown of the Franklin River (Sydney: George Allen \& Unwin, 1984).

${ }^{32}$ Geoff Law, The River Runs Free: Exploring and Defending Tasmania's Wilderness (Camberwell [Victoria]: Viking/Penguin, 2008), 151.

${ }^{33}$ Law, River Runs Free, 185.

${ }^{34}$ Hay, 'Blarsted Hills', 70.

${ }^{35} \mathrm{Hay}$, 'Blarsted Hills', 70.

${ }^{36}$ Hay, 'Blarsted Hills', 70.

${ }^{37}$ Hay, 'Blarsted Hills', 71. 
It would seem, on the basis of the foregoing, that Queenstown is not likely to be a community in which any articulated sense of moral ecology would be evinced. The mine closed in 1993 after a century of continuous operation, re-opened on a dramatically reduced scale (and with a very much smaller workforce) as Copper Mines of Tasmania in 1995, closed again in 1998, then resumed production until closing again in 2014. It has remained idle ever since, though it is in caretaker mode, and stories of a restart as a high-tech "green mine", employing only a small and specialised workforce of skilled technicians, continue to circulate. ${ }^{38}$

In late 1993, with the mine's closure certain and imminent, I had a chance to test community views first-hand. The company had earlier negotiated a site rehabilitation plan with the government, and was now legally obliged to put it into practice. Central to the commitment was an ambitious revegetation program ("the reveg") for the large area of the mine lease. To say that "the reveg" was unpopular with the community is an understatement. Finding itself in a bind, being obliged by law to activate a legal requirement for which there seemed no communal support, and with every chance that the program would be subject to sabotage, I was engaged by government to conduct a community consultation, aimed at determining the strength of communal opposition to "the reveg", and to ascertain what it was, exactly, locals wanted to see happen to the hills.

I found, as expected, an extremely anti-green community, but no longer fanatically so. Parks and Wildlife was still a deeply unpopular face of government, but the Hydro-Electric Commission, the most visible official face of the industrial productivism central to the town's long-standing sense of place, was also unpopular. Most surprisingly, the World Heritage Area (the designation of which, just prior to the 1982 state election, had given the federal government the constitutional trigger it need to fulfil its 1983 election promise and halt construction of the dam) was largely accepted. Attention had now turned to how the WHA could be put to good economic use.

Rather than the WHA itself, it was the perceived preservationist philosophy underpinning it that was the focus of antagonism. Typical of the responses I received was this:

They say people come here to experience wilderness, but driving through a tunnel of trees, is that experiencing it? You have to get people into the middle of it. Into the bays on the coast, for example, and where the Huon pine is. We should be running day and half-day walks into the wilderness from here, but the government doesn't encourage that, because their definition of wilderness is that no-one goes into it - you look at it from the outside. Parks and Wildlife want to close things up. We want to develop it. ${ }^{39}$

Several aspects of this observation intrigue. This is a mere decade on from the tumult of the Franklin Dam debate. A decade on from a tangible transference of hatred of green people to the objects of green reverence. The above observation could not, I think, have been made by a typical

\footnotetext{
${ }^{38}$ For example, $A B C$ News, Hobart, 'Mount Lyell Copper Mine Restart Moves Closer after \$9 Million Cash Injection', April 28, 2017.

${ }^{39}$ Hay, 'Blarsted Hills', 72.
} 
Queenstowner at the end of 1983. In this observation we have agreement that the wild lands merit experiencing. That people should experience them. And that the people of Queenstown are best placed to direct outsider experience; further, to hold custodianship of those wild places. It is an articulation of a frustrated moral ecology.

I was intrigued by my interviewees' attitude towards trees. It was certainly the case that most Queenstowners wanted the hills to remain treeless, because the denuded mountain backdrop was what gave the town its signature as an exceptional place: "for most people the fate of the hills had come to symbolise the fate of the town itself." 40 There was much complexity in this response, and it should not be taken as a dislike of trees per se. In part it is a response from self-interest. The bare hills constitute a formidable firebreak in a region excessively fire-prone, and as the bush was returning with ever greater rapidity in the quarter-century since the closing of the smelters, the risk that wildfire posed to the town was growing by the summer. But as I have noted, "most respondent sentiment was of a loftier nature. The affectionate regard with which the bare hills are held surfaced again and again in interviews", such that "the hills constitute the single most important icon of the people of Queenstown's sense of belonging to this place." ${ }^{41}$ It should be noted that by 1993 the hills were no longer that stark "eye-blinding white" to which I was subjected when working there in the late 1960s. By 1993 the hills, though still largely devoid of trees, had taken on an array of subtle and complex colouration, evidence of the simpler organisms that had colonised the slopes and valleys over the preceding 25 years. As one interviewee said:

Everyone thinks trees are beautiful, but other things are beautiful. The colours in the rocks are beautiful. You should see the colours in the rocks on a fine summer sunset. It's got all the colours in it. Red. And the white is a beautiful white. The black is the jettest black. And we've got hundreds of miles of bush either side of the town. Why would anyone want to put trees here, too. ${ }^{42}$

Again, such views suggest a state of mind receptive to the relationships of reciprocity that constitute a moral ecology, though a sense of a lack of agency was frustrating its realisation. In this case, the welcomed softness of the complexly coloured landscape that had succeeded the dazzling whites of yesterday presaged an eventual return of trees to the hills and mountains.

In constructing a place mythos with the defoliated hills at its centre, Queenstowners also had to confront the indignity of outsider reactions that were typically discordant, often primed by guidebooks telling the prospective visitor to expect to be horrified. In 1993, most Queenstowners were accepting of this, though not always complacently. As I have written:

One interesting response - quite common, whilst not a majority response - constitutes a retreat from the heroic construction of Queenstown; an acknowledgement that the past should have unfolded differently. A sample: "We could hold it [the bare hills] up as a

\footnotetext{
${ }^{40}$ Hay, 'Blarsted Hills', 73.

${ }^{41}$ Hay, 'Blarsted Hills', 73-4.

${ }^{42}$ Hay, 'Blarsted Hills', 74.
} 
monument to what can happen, and don't let it happen again. A scar. A reminder of what we need to avoid." ${ }^{\prime 43}$.

The majority position, by contrast, was an assertion of the weltanschauung of long standing, "an aggressive affirmation of the heritage value of the cultural against the natural - an affirmation of the heroic project and an insistence on the rightness of ensuring its fair treatment by posterity." 44 As one interviewee put it: "It's the destruction of the human history that concerns me. What Parks and Wildlife are doing to the Raglan Road, the lighthouse, Jane River. God that makes me mad. It's the preservation of the mining heritage that should happen here." ${ }^{\prime 5}$

Even when affirming the tenacity of Queenstown's venerable place narrative, the Queenstowner of 1993 was a more nuanced person than the Queenstowner of 1983. The place story was slowly ecologising; the rift between community and ambient landscape was starting to close. The affirmation of the cultural was not always, or even often, a rejection of the natural. Instead of "we value it at precisely nought" I found people who spoke of trees with an unashamed affection, informing me, with a conspiratorial hush of tone, that they knew where to find as fine a stand of sassafras or King Billy pine as grew on the island, and to guarantee its security they were revealing its locality to no-one, least of all to a transient such as myself. ${ }^{46}$ In some instances these were the same informants who staunchly articulated the old and familiar values.

None of this amounted to a fully-rounded moral ecology sensibility. It was, rather, a moral ecology in-waiting, one fit to evolve in the years ahead - given favourable material conditions - into the sort of vernacular ecology, one in which the cultural and natural seamlessly blend, that I had earlier catalogued in the case of the small sawmilling community of the upper North Esk, on the other side of the island.

I stowed my recorder and clipboard and returned to Hobart, my report to government following, roughly, these lines:

Given that Queenstowners want the hills to remain bare, and given that the regrowth is returning at an ever-quickening rate, what interventionist strategies were strongly supported? Strangely - none. The most common response - by an impressive margin - was a wistful "let nature take its course". Leave us our hills for the moment, but let there be no chemical defoliation, and no army of the unemployed scrambling on the mountainside pulling out the resurgent bush. My impression was that this was not the counsel of despair and hopelessness, but a rather more complex response, Buddhist almost, and certainly a long way from the image of redneck ratbaggery that... [is the] outsider's construction of Queenstown. ${ }^{47}$

\footnotetext{
${ }^{43}$ Hay, 'Blarsted Hills', 75.

${ }^{44}$ Hay, 'Blarsted Hills', 75.

${ }^{45}$ Hay, 'Blarsted Hills', 75.

${ }^{46}$ Hay, 'Blarsted Hills', 73.

${ }^{47}$ Hay, 'Blarsted Hills', 76.
} 


\section{Queenstown Today: A Moral Ecology for the Present?}

Robert Sticht, mercurial metallurgist whose pyritic smelter wrought more spectacular damage to Tasmania's natural systems than any other single post-European environmental intervention, was a nature-loving conservationist. A member of Tasmanian Field Naturalists, ${ }^{48}$ his "sympathy for the preservation of the natural environment" was such that "in 1911 he wrote to parliamentarian Sir Elliot Lewis... with a plea for saving the Gordon River from the 'desecration' of the construction of a saw milling enterprise on its banks," and warning of "the damage to the present beauties of the river."'"49

In no way can Robert Sticht be made to fit the moral ecology paradigm. But this does illustrate the attitudinal complexity behind human relationships with the natural world. One of the most valuable lessons from Jacoby's work is his insistence that the proof of the pudding must be in the eating. The principles that inform an individual and a community's being-in-place must structure a way in which aspects of the ambient environment are utilised in practice that is nonetheless conducive to longterm ecological vitality. We need to acknowledge that the mere possession of nature-positive attitudes is not a sufficient condition (though it is certainly a necessary one) to configure a moral ecology. Back to Queenstown in 1993, then.

1993 is a quarter of a century ago. I have deliberately used past tense in the previous section of the paper, because what I found in 1993 is not necessarily what I would find if I were to replicate the exercise today. Given that the responses I gathered in 1993 are counter-intuitive for "the most antigreen town in Tasmania", the question arises: could I have found similar responses back in 1983, a decade earlier? Except at the margins, I doubt it. I doubt that the attitudinal complexities exhibited by the legendary mine manager of Queenstown's formative years would have been much in evidence in Queenstown at the height of the Franklin Dam fracas, excepting perhaps in the case of a small few individuals, but these would have kept their heads down during the white heat of outrage that prevailed, letting others define the communal place meanings (a "key informant', one of several people interviewed by the author in 2017 , stated that one prominent local "used to run a safe house for greenies, though this is disputed," and that it is now possible "to find people who say 'even at the time I was an environmentalist but I never let it out'" (key informant A, interviewed April 19, 2017). As I have argued, the problem is that Queenstowners were never afforded the conditions within which they might develop a sense of moral ecology. For decades the dominance of the mine and the muscular, hegemonic values that stemmed therefrom meant that interactions with "the bush" were occasional and utilitarian in the extreme, and certainly not conducive to the sort of understanding of ambient ecological processes that I identified in my study of the small-scale sawmillers of the upper North Esk. It could be argued, in any case, that Queenstowners were not dependent on a regime of reciprocity in order for nature to keep supplying what they wanted from it (in contrast to regimes based upon natural "product" that grows). Nature is not going to replenish itself with minerals if you treat it kindly - so it could be argued that there was never a real need to include relations with nature in any moral code. The evidence from my interviews of 1993 would seem to confound this view, however.

\footnotetext{
48 Gaunt, Robert Sticht, 12.

${ }^{49}$ Gaunt, Robert Sticht, 12-3.
} 
A decade later the communal world view of the people of Queenstown was becoming more complex, more receptive to a values framework that could foster the development of a moral ecological sensibility. Again, though, the top-down management prescriptions of the World Heritage Area now established on the town's doorstep seemed to preclude any possibility for intensive economic engagement. The perception of Queenstowners at the end of 1993 was that they had been frozen out of the WHA. What has happened in the quarter of a century since? Does a moral ecology based upon "informal rules of reciprocity" now exist? In short, no. Such relationships exist. But they do not constitute moral ecology.

In 2015 I renewed an active engagement with Queenstown, courtesy of a LARQ residency. LARQ (Landscape Art Research Queenstown) was in the tenth and final year of its existence, having been established in 2006 by nationally prominent artist and new Queenstown resident, Raymond Arnold. LARQ'S charter was "to develop a wilderness art space and artist residency program exploring the natural and heritage values of the region," ${ }^{150}$ and during its ten-year existence "it hosted five funded international artist residencies, five unfunded international residencies, staged nineteen exhibitions, managed eleven art workshops, mentored young local students and welcomed many visitors to its gallery [located in the main living space in the home Arnold shared with his artist partner, Helena Demczuk] for openings, artist talks, 'arts industry' nights and casual visits." ${ }^{51}$ It was a "community development business fostering connections, sense of place and artistic interventions in the contested space of the west where wilderness branding slugs it out with the technological forces of the mining, forestry and power industries - a hotspot in the constant debate between development and conservation forces in Tasmania." ${ }^{2}$ Queenstown is "a unique place," Arnold was quoted as saying. "With this completely unique World Heritage Area and this incredible mining heritage that exists here, the clash of the two things is a very powerful thing." 53 Though his presence in the town was initially resented by many, Arnold became a local maker and shaker, a person whose force of character and clarity of vision was in large part responsible for creating a radically new place meaning for Queenstown - one of a town of high artistic sensibility.

Along with LARQ, there are two prominent signifiers of change in Queenstown. They are also major contributors to that change. These are the reopening of the railway that had formerly linked the mining town with its industrial port, Strahan, as a wilderness-experience tourist railway, and the nationally-profiled fine art festival, "The Unconformity".

\footnotetext{
${ }^{50}$ Emily Woods, "Arnold Finishes LARQ Work," The Advocate (Tasmania), February 12, 2015.

51 "About LARQ - landscapeartresearchqueenstown," accessed March 31, 2018, https://landscapeartresearchqueenstown.wordpress.com/about-larq-2/.

${ }^{52}$ About LARQ.

${ }^{53}$ Woods, "Arnold Finishes LARQ."
} 
At the end of 2002 the $35 \mathrm{~km}$ railway between Queenstown and Strahan reopened. No longer, though, was this the old industrial lifeblood between a mining town and its port. It was now a "wilderness experience" and the old Mount Lyell Mining and Railway Company had given way to the West Coast Wilderness Railway. It shut for several months in 2013, when its licensee, Federal Hotels, bailed out with minimal warning, but some months later it reopened with different operators and its future now seems assured. As with LARQ, "the wilderness railway" has played no small part in the reconfiguration of Queenstown's profile away from mining town to tourist centre with the natural world at the centre of what it has to offer. It also gives jobs to locals, offsetting in large part the perceived absence of opportunities to profit from direct involvement with the World Heritage Area. In any case, the lack of economic opportunities available in the WHA that was the source of such frustration in 1993 was later to change, and there are now wilderness tour enterprises operating out of Queenstown.

In 2010 a biennial Queenstown Heritage and Arts Festival was inaugurated. It ran until 2016, when it was rebranded "The Unconformity". In its original incarnation the festival was unashamedly nostalgic, an uncomplicated celebration of the town's mining heritage. In its subsequent incarnation that heritage is retained in part. The town's past remains central to the new conception. But there has been a shift in emphasis from heritage to art - the new version, indeed, promotes itself as a festival of the "high" arts. "It's part of the change from being solely reliant on mining," festival Director, Travis Tiddy (a man of impeccable Queenstown provenance) was quoted as saying at the time. $^{54}$ The present author is on the Artistic Directorate of the 2018 festival, to be held in October, and can affirm that the intent is to step even further away from uncritical celebration of the past, with a more overt questioning of aspects of the town's values heritage (further confirmed in conversation by key informant B, interviewed April 19, 2017). The festival's website foreshadows this, speaking not of an unproblematic past, but of "remarkable cultural paradoxes." 55

It was noted earlier that Queenstown has never accepted that mining towns inevitably pass away. And it has not, though it has had to metamorphose to survive - and nothing that has occurred, since the body blows endured in the 1960s, has been able to halt the ebbing away of population. In the 2016 census the town's population was a mere $1790 ;{ }^{56}$ attrition from a decade earlier, when the census recorded 2117 , being very much in evidence. ${ }^{57}$

Possibly more significant than population decline, though, is a dramatic demographic change, one that may have been imperfectly picked up by the Census. "Fifty-five percent of the people living here now weren't here five years ago," was the observation of one prominent local (key informant $\mathrm{C}$, interviewed April 19, 2017), though the most recent Census reported that the percentage was

\footnotetext{
${ }^{54}$ Carla Howarth, "Queenstown's The Unconformity Arts Festival Helps Mining Region Evolve, Celebrates Past," ABC News, October 15, 2016, http://www.abc.net.au/news/2016-10-15/the-unconformity-arts-festivalbegins $/ 7935670$.

55 "Unconformity, The," accessed January 28, 2018, https://theunconformity.com.au/

${ }^{56}$ Australian Bureau of Statistics, "2016 Census QuickStats," accessed March 31, 2018, http://www.censusdata.abs.gov.au/census services/getproduct/census/2016/quickstat/SSC60526
}

${ }^{57}$ Australian Bureau of Statistics, "2006 Census QuickStats," accessed March 31, 2018, http://www.censusdata.abs.gov.au/census services/getproduct/census/2006/quickstat/UCL613200 
almost precisely 33 percent. ${ }^{58}$ Even at the official rate of turnover, over a ten-fifteen year period the outcome will be a reconstituted community. Who are the newcomers? "People trying to find a bolthole who have run out of options elsewhere - damaged people. And some authors. Other creatives. Climate refugees sick of the heat elsewhere. Some with capital and entrepreneurial skills - not many of these, but they are important. And they're all slightly nutty" (informant B). A similar, though not identical view was articulated by informant $C$. He instanced men whose marriages or farms had gone bust, and "people who say quite openly, 'it was too hot up there in Queensland.' Every year there is a flotsam and jetsam ebb and flow. About one in four stay on." Key informant A does give more credence than key informant $B$ to the cohort of artists and environmentalists who have arrived, whilst key informant D (interviewed April 20, 2017) dramatically declaimed: "this has become a town of artists and environmentalists." Certainly this is overstated, but such people, "those who are a bit spiritual," are more inclined to stay than professionals or those further down the social scale (according to informant A). Concerning the latter, most of the influx occurs in the summer, with the ready availability of cheap, albeit humble, housing a major attractor. Having endured a West Coast winter many of these people subsequently decamp. When the mine closed the professionals left (observation of informant B) whilst, of the pick and shovel miner population, from whom Queenstown's anti-green culture drew its oxygen, few remain. Informant A puts it at 20 percent (their now grown-up offspring included). "Those who didn't leave are dead or going into old folks' homes, and their kids left ages ago," said informant B. This seems to be largely but not entirely accurate. The Unconformity in 2016 featured a "night club." One journalist flown in to cover the event observed: "each night the festival club resembles the late hours of an unlikely wedding, with boundaries between locals and incomers dissolving on the dance floor where Bruce Springsteen, as ever, proves the great unifier." ${ }^{159}$ In fact, the boundaries failed to perfectly dissolve. Tensions boiled over on at least one occasion at the night club, with the young of "old Queenstown" reacting physically to the presence of city hipsters. At least some continuity with the past, then, is still in evidence.

The most tangible evidence of continuity with the past is the Miners' Siding memorial on the decommissioned line of rail from the town station to the mine. In recent years a series of bronze sculptures portraying 21 "stations" in the pioneering history of the town has been installed at Miners' Siding. These are extreme valorisations of the old values of the West Coast. The central plaque reads thus:

Over five generations of Tasmanians have mined for copper, zinc, tin, iron, lead, silver and gold. Mining has been a prime factor in the community life of the West Coast region, and a major contributor to the Tasmanian economy. With less than $2 \%$ of the States [sic] population, the West Coast produces $35 \%$ of the States wealth. The hard working pioneer spirit of these mining communities lives on today...

\footnotetext{
${ }^{58}$ Australian Bureau of Statistics, "2016 Census QuickStats, Community Profiles - Queenstown, G42" accessed May 27, 2018, http://www.censusdata.abs.gov.au/census services/getproduct/census/2016/quickstat/SSC60526

${ }^{59}$ Rowe, Josephine, "The Unconformity: Devastation and Beauty Collide in Isolated Tasmanian Mining Town," The Guardian, October 21, 2016.
} 
We can conclude that the town that exists today has been able to proudly carry its past with it, without any sense of incongruity. It can do this because those values have now become historically bounded, no longer constituting a fulcrum of conflict in the present.

The best signifier of change is to be found in the shifting shape of politics. "if you hadn't gone through the turbulent times of the Franklin Dam blockade you don't have that antipathy towards the environmentalists," observed informant B, and "there was a bloke handing out Green Party how-tovote cards at the last election - that couldn't have happened a couple of decades ago." A State Upper House election took place on a day when the present author was in Queenstown. The sitting member was an independent with a progressive voting record. Her opponent was an outspoken champion of the values of the old Queenstown. Both candidates lived on the more populous NorthWest Coast - but the only placards in evidence in Queenstown were those of the progressive incumbent, and whilst she often visited the town during the campaign, her "old school" challenger was nowhere to be seen. She won handsomely.

Queenstown is a mining town, then, that has bucked reality. It did not die, but it almost did, and to live on it has had to become something else. With the passing of traditional Queenstown a fledgling moral ecology was stillborn, though the newcomers seem to have brought with them a more generalised, less context-specific set of environmentalist values. There is an ominous, more general lesson here for moral ecology.

\section{Conclusion}

Thompson assumed that the moral economy could not withstand a new world in which economic relationships, vastly more complex in the wake of the industrial revolution, were rationalised and codified. Where such relationships were based upon long-standing socially-sanctioned practices of reciprocity and sustainability in the matter of community/ambient environment interchange, a condition described by Jacoby as "moral ecology", Thompson's scepticism can be largely discounted. I say "largely", because the conditions that create and sustain a moral ecology are fragile - and are especially precarious in times of demographic fluidity.

Queenstowners were denied meaningful interaction with their hinterland for the 90-odd years that followed the mining town's creation by, firstly, the grip of the muscular industrial place myth that set human endeavour and the natural world within a fiercely adversarial, zero-sum relationship, and, secondly, the reality of the total destruction of that natural world for as far as the eye could see. With the mine winding down through the 1980s to its closure in 1994, and the need to reconstruct a local economy in part based upon opportunities for nature-focused tourism within the adjacent Tasmanian Wilderness World Heritage Area, and with the ambient environment re-naturalising rapidly of its own accord, the conditions for the creation of a moral ecology were finally in place, as interviews conducted by the present author with Queenstowners at the end of 1993 demonstrate. 
This did not happen. In part this was because the top-down management prescriptions of the WHA precluded significant local involvement. This has gradually changed, and the tourist economy has come to Queenstown, and with it a different local economic profile. In terms of the argument presented here, though, this came too late - because it is simply no longer the case that Queenstown remains a "traditional" community, one existing in direct descent from those who angrily upheld the old industrial mythology in the confrontational days of the Franklin Dam dispute in the early 1980s. The memory chain has been broken, and the incomers' more positive attitudes towards the natural environment are generalised, not specific. Their environmentalism is abstracted, not based in concrete local knowledge systems. "You talk to people who've been here a few years about the old path to a particular falls," said informant A, "and they don't know what you're talking about."

For a moral ecology to persist through time the community within which the relevant mores were slowly formed also has to persist. The lesson of this paper is that, in times of demographic dynamism, and particularly when the perceived enchantment of exotic small-town life lures an affluent, mobile, unsettled middle class, one cast upon the four winds in search of an elusive authentic way of living, it will become increasingly difficult for those stable, geographically confined communities to resist gentrification. The newly gentrified community is likely to romanticise the way of life of the community that it has displaced, but this is because that way of life will by now have been sealed behind the glass wall of history. The new community is likely to valorise the natural values of the ambient environment, but in ways that do not square with the conditions of "moral ecology" as set down by Jacoby. And if this can happen in the case of grim, cold, wet, remote Queenstown - the last place I would have thought amenable to gentrification - then it can surely happen anywhere.

To Jacoby's conceptual schema, then, the following ideas could usefully be added: that the processes of forming a moral ecology are precarious, certainly not inevitable, and vulnerable to frustration via the intervention of incompatible ideas and historical developments; and that the persistence of relationships of environment/community reciprocity is almost impossible to sustain in times of robust demographic fluidity.

\section{Bibliography}

ABC News, Hobart, 'Mount Lyell Copper Mine Restart Moves Closer after \$9 Million Cash Injection', 28 April, 2017.

Australian Bureau of Statistics. "2006 Census QuickStats". Accessed March 31, 2018. http://www.censusdata.abs.gov.au/census services/getproduct/census/2006/quickstat/UCL613200.

Australian Bureau of Statistics. "2016 Census QuickStats". Accessed March 31, 2018. http:// www.censusdata.abs.gov.au/census services/getproduct/census/2016/quickstat/SSC60526.

Australian Bureau of Statistics. "2016 Census QuickStats. Community Profiles - Queenstown, G42". Accessed May 27, 2018.

http://www.censusdata.abs.gov.au/census services/getproduct/census/2016/quickstat/SSC60526. 
Binks, C.J. Pioneers of Tasmania's West Coast. Hobart (Tasmania): Blubber Head Press, 1988.

Blainey, Geoffrey. The Peaks of Lyell, $3^{\text {rd }}$ edn. Carlton (Victoria): Melbourne University Press, 1967.

Bonyhady, Tim. "The Photo That Changed Us." Weekend Australian, Features Section, April 20-21, 1996.

Brown, Bob. "Wilderness Versus Hydro-Electricity in South West Tasmania." In Fighting for Wilderness: Papers from the Australian Conservation Foundation's Third National Wilderness Conference, edited by J.G. Mosley and J. Messer, 59-68. Sydney: Fontana/Australian Conservation Foundation, 1984.

Buckman, Greg. Tasmania's Wilderness Battles: A History. Sydney: Allen \& Unwin, 2008.

Chen, Henry, and Hay, Pete. "Dissenting Island Voices: Environmental Campaigns in Tasmania and Taiwan". In Proceedings, Islands of the World VIII: Changing Islands - Changing Worlds, 1110-1131. Kinmen Island, Taiwan: 2004.

Davis, Bruce W. "The Struggle for South-West Tasmania." In Interest Groups and the Policy Process: Case Studies from the Australian States, edited by Roger Scott, 152-69. Melbourne: Macmillan, 1980.

Easthope, Gary, and Holloway, Geoff. "Wilderness as the Sacred: The Franklin River Campaign." In Environmental Politics in Australia and New Zealand, edited by Peter Hay, Robyn Eckersley and Geoff Holloway, 189-201. Hobart (Tasmania): Occasional Paper 23, Centre for Environmental Studies, University of Tasmania, 1989.

Gaunt, Heather. "Robert Sticht and the Relics of the Past". In The Jewelled House of Art and Nature: The Mt. Lyell Mining and Railway Company Office, edited by Raymond Arnold and Travis Tiddy, 5-19. Queenstown (Tasmania): Mt Lyell Office Development Committee, 2010.

Godfrey, Margery. Waratah: Pioneer of the West. Waratah (Tasmania): Municipality of Waratah and Morevale Investments, 1984.

Green, Roger. Battle for the Franklin: Conversations with the Combatants in the Struggle for South West Tasmania. Sydney: Fontana/Australian Conservation Foundation, 1984.

Hay, Pete. "Will the Tasmanian Disease Spread to the Mainland?: The Politics of Tasmania's World Heritage Area." Current Affairs Bulletin 63, no. 3 (August 1987): 4-12.

Hay. Pete. "'These Blarsted Hills': Affectionate Regard for a Despoliated Landscape", In Vandiemonian Essays, 59-78. Hobart (Tasmania): Walleah Press, 2002.

Hay, Pete. "Balding Nevis': Place Imperatives of an Invisible Cohort within Tasmania's Forest Communities." Geographical Research 46, no. 2 (June 2008): 224-233.

Haygarth, Nic. Baron Bischoff: Philosopher Smith and the Birth of Tasmanian Mining. No place listed: self-published, 2004.

Howarth, Carla. "Queenstown's The Unconformity Arts Festival Helps Mining Region Evolve, Celebrates Past." ABC News, October 15, 2016. http://www.abc.net.au/news/2016-10-15/theunconformity-arts-festival-begins/7935670.

Jacoby, Karl. Crimes against Nature: Squatters, Poachers, Thieves and the Hidden History of American Conservation. Berkeley, Los Angeles and London: University of California Press, 2001.

LARQ. “About LARQ - landscapeartresearchqueenstown.” Accessed March 31, 2018.

https://landscapeartresearchqueenstown.wordpress.com/about-larq-2/. 
Law, Geoff. The River Runs Free: Exploring and Defending Tasmania's Wilderness. Camberwell (Victoria): Viking/Penguin, 2008.

Lowe, Doug. The Price of Power: The Politics Behind the Tasmanian Dams Case. South Melbourne (Victoria): Macmillan, 1984.

McQueen, James. The Franklin: Not Just a River. Ringwood (Victoria): Penguin, 1983.

Marx, Karl, and Engels, Friedrich. The German Ideology. London: Lawrence \& Wishart, 1965 (ms 1846).

Parks and Wildlife Service Tasmania. "Buttongrass Moorland - A Unique Habitat." Accessed August 18, 2017. www.parks.tas.gov.au/?base=3224.

Pybus, Cassandra, and Flanagan, Richard, eds., The Rest of the World Is Watching: Tasmania and the Greens. Sydney: Pan Macmillan, 1990.

Rae, Lou. The Abt Railway on Tasmania's West Coast. Sandy Bay (Tasmania): self-published, 1988.

Rowe, Josephine. "The Unconformity: Devastation and Beauty Collide in Isolated Tasmanian Mining Town". The Guardian, October 21, 2016.

Ann G. Smith. "Murray, Russell Mervyn (1877-1945)." Australian Dictionary of Biography. Accessed May 22, 2018. http://adb.anu.edu.au/biography/murray-russell-mervyn-7713/text13509, published first in hardcopy 1986.

Sornarajah, M., ed. The South West Dam Dispute: The Legal and Political Issues. Hobart \{Tasmania\}: Sir Elliot Lewis Memorial Publication University of Tasmania, 1983.

Thompson, E. P. "The Moral Economy of the English Crowd in the Eighteenth Century." Past and Present 50 (February 1971): 76-136.

Thompson, E.P. Customs in Common. New York: The New Press, 1993

Thompson, Peter. Bob Brown of the Franklin River. Sydney: George Allen \& Unwin, 1984.

Unconformity, The. "Unconformity." Accessed January 28, 2018. https://theunconformity.com.au/.

Whitham, Charles. Western Tasmania: A Land of Riches and Beauty. Queenstown (Tasmania): Board of Management, Robert Sticht Memorial Library, 1949.

Woods, Emily. "Arnold Finishes LARQ Work". The Advocate (Tasmania), February 12, 2015. 